\title{
Healthcare, development and innovation
}

Over the course of the last century, the role of innovation has been recognized as a driving force behind the advent of capitalism. Consequently, those policies aimed at promoting innovation, as well as knowledge-intensive sectors, have gained a prominent role within contemporary society. Schumpeter ${ }^{1}$ declaredly influenced by the likes of Marx, Schmoller and Sombart, identified the crucial nature of innovation as a source of competitiveness, economic development and social transformation. Systematic studies that followed essentially focused on the scientific foundations of innovation and on its technological infrastructure, indicating certain paradoxes of innovation resulting from the systemic fragility of theoretical analysis in this area and of the indicators on which it is based 2. During the late 1980s, these reflections led to the emergence of the National Innovation Systems' (NIS) approach, through the pioneering work of Freeman, Lundvall and Nelson.

Despite the fact that the NIS theory originally recognized the central role of learning and knowledge 3 , Lundvall 2 points out that its transformation into a potential commodity, subjugated to the logic of international competitiveness, should be attributed to the dominant neoliberal strain of contemporary capitalism. This fact implies a growing subordination of knowledge to market demands, something that can be seen, for example, in successive attempts to extend intellectual property rights to beyond the point recommended for the promotion of socioeconomic progress.

There is still some way to go in our understanding of the innovation dynamic in healthcare, either because of our as yet limited knowledge of determinants involved in producer-user interaction, and the historical, geographical and innovation characteristics of the service sectors, or, especially, because of the non-observance of issues relating to power and subsequent underestimation of conflicts. The incorporation of political elements into our understanding of the contradictions that are characteristic tothis field is, therefor, vitally important.

Since healthcare articulates a range of different technologies, it exerts, while at the same time, absorbing an influence on the standard of knowledge that is generated and disseminated. The challenge is, therefore, to discover how one shoul consider and question the two senses invoked by the expression "healthcare and innovation": one that responds to the determinations of a competitive international insertion (market), and one in which the population's risks of becoming sock are social (part of a civilizing and democratizing process). Based on this, affirming healthcare as a common good, a right to life in modern societies and a vector for sustainable development.

The web of intrigue that surrounds the interaction and competition between public and private interests only increases the complexity of formulating policies aimed at innovation in healthcare systems. The choice, adherence to and dissemination of certain technological trajectories between them condition the structure of healthcare networks. In a vast and unequal country like Brazil, which has its own universal healthcare system, it is important to know whether the technologies that have been incorporated by the system are available to all, or only to a restricted few; in other words, whether they reproduce and heighten inequalities, or whether they contribute to overcoming them. 
According to Feenberg 4, knowledge should include a range of interests that is much more diversified than current one; it could thus become an instrument for transforming a society, reconciling broader freedoms with substantive forms of material well-being in the service of the population as a whole.

In this context, one should draw attention to the importance of a theory that problematizes innovation in healthcare so that it works toward the emancipation and sustainability and grants voice to individuals. Currently, research and development $(R \& D)$ resources are mainly accessible to privileged segments, resulting in a healthcare agenda that is monopolized by the interests of large multinational conglomerates and of the financial capital. Such conditioners suggest that it would be appropriate incorporate the analysis of political contingencies and controversies into our efforts to understand innovation in healthcare. Such analyses would be based on processes of social differentiation 5 .

These are then challenges that underlie the relationships that exist between healthcare, sustainable development and innovation, and which are jointly a core theme for public healthcare. Their relevance has attracted authors from many different fields, helpnig oxygenate the debate and making important contributions to public healthcare, especially given its multidisciplinar nature.

This debate's pertinence was the main motivation behind the elaboration of this Supplement, which includes 17 articles that try to call into question the contemporary dynamic of development, which has exceedingly affected the reorganization of healthcare systems in recent decades. A systemic approach to healthcare innovation should be more in tune with the views of social actors' and this suggests that we need to review the current social contract between the healthcare system and the nation's citizens in order to better define future policies for healthcare innovation 6 .

Laís Silveira Costa

Escola Nacional de Saúde Pública Sergio Arouca, Fundação Oswaldo Cruz, Rio de Janeiro, Brasil.

lais.costa@fiocruz.br

1. Schumpeter JA. The theory of economic development: an inquiry into profits, capital, credit, interests and the business cycle, London: Oxford University Press; 1938.

2. Lundvall B. Post script: innovation system research. Where it came from and where it might go. In: Lundvall B, editor. National system of innovation: toward a theory of innovation and interactive learning. London: Anthem Press; 2010. p. 317-50.

3. Lundvall B. National innovation systems: towards a theory of innovation and interactive learning. London: Pinter Publishers; 1992.
4. Feenberg A. Critical theory of technology: an overview. Tailoring Biotechnologies 2005; I:47-64.

5. Fischer-Lescano A. A teoria crítica dos sistemas da escola de Frankfurt. Novos Estudos CEBRAP 2010; 86:163-77.

6. Horne R, Bell JI, Montgomery JR, Ravn MO, Tooke JE. A new social contract for medical innovation. Lancet 2015; 385:1153-4. 